\title{
Histone-Lysine N-Methyltransferase 2C
}

National Cancer Institute

\section{Source}

National Cancer Institute. Histone-Lysine N-Methyltransferase 2C. NCI Thesaurus. Code C93093.

Histone-lysine N-methyltransferase MLL3 (4911 aa, 541 kDa) is encoded by the human MLL3 gene. This protein plays a role in histone methylation that regulates gene transcription. 